NBER WORKING PAPER SERIES

\title{
POLITICAL INSTABILITY AND ECONOMIC GROWTH
}

\author{
Alberto Alesina \\ Sule Özler \\ Nouriel Roubini \\ Phillip Swagel
}

Working Paper No. 4173

\section{NATIONAL BUREAU OF ECONOMIC RESEARCH 1050 Massachusetts Avenue \\ Cambridge, MA 02138 \\ September 1992}

We are grateful to John Londregan for generously sharing his data set and for useful conversations, Kala Krishna for letting us use her PC, Jennifer Widner for much needed help in understanding political events in Africa, Gary King for providing some data, Robert Barro, Rudi Dornbusch, John Helliwell, Ed Learner, Nancy Marion, Ronald Rogowski, Howard Rosenthal, and participants in seminars at University of Maryland, Pennsylvania, Princeton, Utah, UCLA and NBER for very useful comments and Gina Raimondo and Jane Willis for excellent research assistance. For financial support we thank National Fellows Program at Hoover Institution, Sloan, UCLA Academic Senate and Yale Social Science Research Fund, and especially IRIS at University of Maryland. This paper is part of NBER's research programs in Growth, International Finance and Macroeconomics, and International Trade and Investment. Any opinions expressed are those of the authors and not those of the National Bureau of Economic Research. 
NBER Working Paper \#4173

September 1992

\section{ABSTRACT \\ POLITICAL INSTABILITY AND ECONOMIC GROWTH}

This paper investigates the relationship between political instability and per capita GDP growth in a sample of 113 countries for the period 1950-1982. We define "political instability" as the propensity of a government collapse, and we estimate a model in which political instability and economic growth are jointly determined. The main result of this paper is that in countries and time periods with a high propensity of government collapse, growth is significantly lower than otherwise. This effect remains strong when we restrict our definition of "government change" to cases of substantial changes of the government.

\author{
Alberto Alesina \\ Department of Economics \\ Harvard University \\ Cambridge, MA 02138 \\ and NBER \\ Sule Özler \\ National Fellows Program \\ Hoover Institution \\ Room 203L \\ Stanford University \\ Stanford, CA 94305 \\ and NBER
}

\author{
Nouriel Roubini \\ Department of Economics \\ Yale University \\ P.O. Box 1972 - Yale Station \\ New Haven, CT 06520 \\ and NBER \\ Phillip Swagel \\ Federal Reserve Board \\ 20th Street and \\ Constitution Ave, NW \\ Washington, D.C. 20551
}




\section{Introduction}

Economic growth and political stability are deeply interconnected. On the one hand, the uncertainty associated with an unstable political environment may reduce investment and the speed of economic development. On the other hand, poor economic performance may lead to government collapse and political unrest. This paper studies the joint determination of the propensity of government changes (our measure of "political instability") and economic growth in a sample of 113 countries for the period 19501982.

The primary result of this paper is that in countries and time periods with a high propensity of government collapses, growth is significantly lower than otherwise. This effect is strong for both of the two types of government changes considered: all government turnovers including those that do not involve a significant change in ideological direction or an "irregular" transfer of power or alternatively those government turnovers that involve only these two types of changes.

Our other results are: 1) Contemporaneous low economic growth is not found to increase the contemporaneous propensity of government changes. 2) We do not find any evidence that economic growth is significantly different when authoritarian regimes are compared to democracies. 3) We find that political instability tends to be persistent, in that the occurrence of frequent government collapses increases the probability of additional collapses.

This is not the first paper which studies the relationship between economic outcomes and political instability in a large sample 
of countries. ${ }^{1}$ Notably, Barro (1991) finds that measures of political unrest, such as number of assassinations and the occurrence of violent revolutions and military coups significantly affect the average growth level in cross section regressions on a large sample of countries. In addition, Kormendi and McGuire (1985) and Barro (1989) find that a measure of the extent of political rights is positively correlated with growth.

Other studies which have adopted a notion of political instability similar to ours have found effects of instability on inflation (Cukierman, Edwards and Tabellini (1992)), and on external borrowing (Özler and Tabellini (1991)). In these papers, a measure of political instability is added as a regressor in cross section or panel regressions; however, this methodology does not take into account the joint endogeneity between the economy and the polity.

Londregan and Poole (1990, 1991a) have addressed this problem of joint endogeneity by estimating a system of equations in which the dependent variables are GNP growth and coups d'etat. ${ }^{2}$ Their results are different from ours, in particular in that they do not find evidence of reduced growth as a consecuence of increased political instability. Our study differs from theirs in several important respects. First, in model specification. In our growth equation we control for several economic determinants of growth, as identified by the recent empirical literature on economic growth, as well as some indicators of political unrest in the government change equation. In addition, we do not primarily focus on "coups d'etat" but on a broader definition of government changes, which includes not only coups but also 
constitutional transfers of power: political uncertainty is not confined to the occurrence of military coups. We present some results based on our specification focusing only on coup detat so as to suggest the sources of differences in the results of these two sets of works.

This paper is organized as follows. Section 2 discusses the basic questions which we explore in our empirical analysis. Section 3 presents the econometric methodology used both for the by now familiar in the cross-sectional methodology and for the joint estimation of the growth and government instability equations using panel data. Section 4 describes our data set, highlights some basic statistics and describes the specification used in the estimation of the cross-section and panel models. In Section 5 we present our cross-section regressions of growth. The main results of the panel estimation of our simultaneous equation system are discussed in Section 6. Section 7 presents alternative specifications so as to investigate the robustness of our results. The last section is a discussion of future avenues of research.

\section{Does political instability affect economic growth?}

The first step toward answering this question is a definition of what it is meant by "political instability". In this paper, "political instability" is defined as the propensity of a change in the executive, either by "constitutional" or "unconstitutional" means. Thus, we study whether a high propensity of an executive collapse leads to a reduction of growth. 
One strong theoretical argument underlying this relationship is based upon the effects of uncertainty on productive economic decisions, such investment, production or labor supply. ${ }^{3}$ A high propensity of a change of government is associated with uncertainty about the new policies of a potential new government; risk-averse economic agents may hesitate to take economic initiatives or may "exit" the economy, by investing abroad. Conversely, foreign investors prefer a stable political environment, with less policy uncertainty and less uncertainty about property rights. ${ }^{4}$

Alesina and Tabellini (1990), Tabellini and Alesina (1990), Cukierman, Edwards and Tabellini (1992), Özler and Tabellini (1991) present several models in which a government is uncertain about its survival, and as a result engages in suboptimal policies in order to "worsen" the state of the world inherited by its successor. ${ }^{5}$ All these models have in common the idea that political instability lead to economic inefficiencies. ${ }^{6}$ The most direct application of this idea for economic growth is in Alesina and Tabellini (1989), which examines the effect of political uncertainty on investment and capital flight. The possibility of a government collapse leading to a new government prone to tax capital and productive activities implies a substitution of productive domestic investments in favor of consumption and capital flight, and thereby leads to a reduction of domestic production.

A different argument leading to a similar relation between political instability and growth is implied by Grossman's (1991) analysis of revolutions. In countries where rulers are relatively weak, i.e. more easily overthrown, the probability of revolutions is higher and 
the citizens have higher incentives to engage in revolutionary activities rather than productive market activities. On the contrary, a strong ruler who makes a revolution unlikely to succeed discourages revolutionary activities in favor of market activities.

A related line of research, in particular the work by Murphy, Shleifer and Vishny (1991) and Terrones (1990), emphasizes the negative effects of rent-seeking activities on economic growth. A weak government constantly under threat of losing office may be particularly sensitive to the need of pleasing lobbyists and pressure groups, thus leading to a more direct effect of rent-seeking activities on policy decisions.

Two objections to these arguments are worth mentioning. The first one is that a high propensity of a government change may be viewed favorably by economic agents if the current government is incompetent and/or corrupt and its possible successors are viewed as an improvement. In a large sample such as ours, it is reasonable to assume that the expected value of the competence of future governments is not higher than the current government competence.

Second, if the propensity of government change is large, an increase of it may actually reduce political uncertainty, since it becomes more certain that the current government will collapse. However, if the characteristics, or even the identity of the successor of the incumbent government are not known with certainty, an increase of the propensity of a political change may lead to an increase in policy uncertainty. In fact, it implies an increase of the propensity of 
substituting a well known (even though, possibly, inefficient) government for a less known one.

A study of the effects of political instability on economic growth needs to deal with the problem of joint endogeneity: even if it is true that a high propensity of having frequent government changes reduces growth, it may also be the case that low growth increases the probability of a government change. The effect of growth on government changes is likely to be observable in both democracies and in dictatorships. In democracies, a vast empirical literature ${ }^{7}$ has established that high growth in preelection years increases the likelihood of reelection of the incumbent government: voters do not reelect incumbents if they perceive that the latter have mismanaged the economy. Specifically, voters appear to pay particular attention to income growth immediately before elections. In non-democracies the likelihood of coups d'etat may also decrease with both the level of GDP per capita and its rate of growth. Low growth may increase popular dissatisfaction and create incentives for anti-government political action. These are, in fact, the results shown by Londregan and Poole (1990), (1991a) in their studies of the economic determinants of unconstitutional transfers of power.

A related issue is whether democratic institutions are harmful or conducive to growth. A rather popular argument is that democratic institutions may be harmful to growth. ${ }^{8}$ The basic idea underlying this view is that policy makers in democratic government are subject to the pressures of interests groups, and thus short-sightedly follow opportunistic policies to enhance their chances of reelection instead of 
policies that enhance long term growth. However, these arguments against democracy are not necessarily conclusive. First of all, dictators may also need to be opportunistic if their survival in office is threatened. Second, authoritarian regimes are not a homogenous lot: they include "technocratic" dictators and "kleptocratic" ones. While the apparent association of high economic growth with authoritarian regimes is suggested by the experience of several authoritarian "technocratic" regimes (such as those in Korea, Taiwan, Indonesia, Turkey, Chile) it is as well evident that for each "benevolent" dictator one can observe at least as many "kleptocratic" and/or inept authoritarian regimes whose rule has led to systematic economic mismanagement and eventual political and economic collapse of their countries. $^{9}$ One can therefore conclude that, both on theoretical and empirical grounds, there is no obvious relationship between democracy and growth.

In fact, the empirical cross-country evidence on the relation between democracy and growth is quite mixed. Some early studies argue that democratic regime tend to slow economic growth while authoritarian regimes tend to stimulate it. ${ }^{10}$ However, others show that there is no systematic relation between long term growth and the democratic/ authoritarian nature of the political regime. ${ }^{11}$ Alesina and Rodrik (1991) present a model which is consistent with this inconclusive evidence. In their model, democracies should grow faster than "populists" or "kleptocratic" dictatorships, but less fast than "right wing" or "technocratic" dictatorships. 


\section{Methodology}

This section describes the procedures employed for the estimation. First, we give a brief discussion of single equation estimation, where cross section growth regressions are considered. The primary purpose of employing this method is to facilitate a comparison of our results with those of other cross section studies in the recent literature such as those of Barro $(1990,1991)$. A major drawback of a single equation approach for our study is that it does not take into account the joint endogeneity of the growth and government change. Hence, later in this section, we turn to a discussion of a simultaneous equation methodology, which constitutes the primary focus of this study.

\subsection{Single Equation Method}

\section{1.a. Political Instability}

Political instability, defined as the propensity of an imminent government change, is not directly observable. Since "government change" is a discrete phenomenon, we employ limited dependent variable estimation methods. Propensity of government change is characterized as a function of economic and political variables. We estimate the probit specification described below using time-series cross-section pooled data (for notational convenience time and country indicators are omitted):

$$
c^{*}=\beta \mathrm{X}_{1}+\eta
$$

where: 
$c^{*}=$ a latent variable such that when $c^{*}>0$ we observe the occurrence of a government change, and we do not observe government change otherwise.

$X_{1}=$ variables (economic and political) that determine the occurrence of government change.

$\eta=$ normally distributed error term with mean zero.

This specification facilitates an estimation of probabilities of government change that varies over time and across countries. We then average these annual measures of probability for each country over time so as to obtain a cross section measure of instability, which we call INS, to use in the cross section growth regressions described next.

\section{1.b. Economic Growth}

A cross section estimation of growth is described with the following specification:

$$
\mathrm{Y}=\lambda \mathrm{X}_{2}+\theta(\mathrm{INS})+\epsilon
$$

where:

$\mathrm{Y}=$ average economic growth in each country for the sample period.

$\mathrm{X}_{2}=$ economic variables that explain economic growth,

INS = measure of political instability, obtained from equation (1) as the average estimated probability of government change over the sample for each country.

$\varepsilon=$ error term with mean zero.

This approach has two problems. First, as instability is a 
generated regressor, the standard errors of the second stage equation are generally inconsistent. ${ }^{12}$ A more serious problem is that of simultaneity. Since the propensity of government change and economic performance are endogenous, equations (1) and (2) are both likely to be biased. We address this issue by using a simultaneous estimation of the two equations for growth and political instability as described next.

\subsection{A Simultaneous Equations Approach}

Let us define the following structural equation system, where the dependent variables of government change and growth are as before (but now both with yearly frequency):

$$
\begin{aligned}
& \mathrm{c}^{*}=\alpha_{\mathrm{c}} \mathrm{X}_{\mathrm{c}}+\beta_{\mathrm{c}} \mathrm{X}+\gamma_{\mathrm{c}} \mathrm{y}+\mathrm{u}_{1} \\
& \mathrm{y}=\alpha_{\mathrm{y}} \mathrm{X}_{\mathrm{y}}+\beta_{\mathrm{y}} \mathrm{X}+\gamma_{\mathrm{y}} \mathrm{c}^{*}+\mathrm{u}_{2}
\end{aligned}
$$

where:

$y=$ annual rate of growth,

$\mathrm{X}=$ exogenous variables that determine both government change and growth,

$X_{c}=$ exogenous variables (economic and political) that determine the occurrence of government change only (i.e instruments for instability),

$X_{y}=$ exogenous variables that determine economic growth only (i.e. instruments for growth),

$\mathrm{u}_{1}, \mathrm{u}_{2}=$ error terms are assumed to be bivariate normally distributed with zero mean and variance covariance matrix that allows for cross-equation correlations.

The coefficients $\gamma_{c}$ and $\gamma_{y}$ take into account the contemporaneous feedback between growth and changes of government, 
while the $\alpha$ and $\beta$ coefficients measure the effects of the exogenous variables. One way of identifying the system requires that at least one each of the $X_{c}$ and $X_{y}$ variables exist; that is, we need one exogenous variable in the growth equation which is not in the equation for government change, and vice-versa. An alternative way of identifying the system of equations is to impose restrictions on the contemporaneous feedback, i.e. $\gamma_{c}=0$ or $\gamma_{y}=0$. In order to test the model (a chi-square test), there must at least be one overidentifying restriction, in addition to the restrictions needed to identify the model fully. We discuss the economic and political variables used as our identifying restrictions in Section 4.

This model, a simultaneous equation system involving a latent variable, is described in Heckman (1978). While this system could in principle be estimated by standard maximum likelihood methods, the resulting likelihood function is extremely non-linear and thus difficult to maximize using standard methods. Londregan and Poole (1990) use the results of Newey (1987) to estimate this type of system through an application of Amemiya's Generalized Least Squares Technique (AGLS). Since we employ the same econometric methodology the technical details are not replicated here (see the Appendix of Londregan and Poole (1990)). Instead, we provide only a heuristic description of the estimation procedure.

The estimation proceeds in two stages: estimation of reduced forms of both equations, and then extraction of the structural parameters from the reduced forms. The likelihood function of the system factors out into the product of the likelihood function 
corresponding to the growth equation and the likelihood function of the probit that corresponds to the government change equation. This greatly simplifies estimation of the reduced form, since the equations can be estimated sequentially. The growth equation is estimated as a function of all the exogenous variables in the system using OLS. The residuals from this regression are then added as a regressor, in addition to all the exogenous variables in the system, for the reduced form of the probit estimation for government change. After adjusting to take into account correlation across the equations, the resulting coefficients are the maximum likelihood estimators of the reduced form parameters. The reduced forms take into account that there may be shocks common to both growth and instability.

The structural form estimates take into account the simultaneous feedback between growth and government change. Fully efficient structural estimates are obtained by a GLS regression of the stacked coefficients from the two reduced form equations against the two "contemporaneous" $(\gamma)$ parameters and a "selection" matrix which picks out the appropriate reduced form coefficients. A bootstrapped estimate of the variance-covariance matrix of the reduced form coefficients (Efron (1982)) is used to form the weighting matrix for the GLS regression. We use 1024 bootstrap replications (so that the number of replications we have are identical to Londregan and Poole (1990)). 


\section{Data and Specification}

This section briefly describes our data and the specification of our equations for political instability and for growth. Our panel data set includes a time series and cross section panel for 113 countries. ${ }^{13}$ For about half of the countries the sample period is $1950-82$, for most of the others the sample is 1960-82. A list of countries and sample period is in Table A.1, in the Appendix.

\subsection{The Specification of the Political Instability Equation}

Our specification for the government change is similar to those employed in the recent literature (Cukierman et al. (1992), Özler and Tabellini (1991)). The independent variables can be classified in three broad classes: 1) indicators of political unrest such as cabinet adjustments; 2) "structural" institutional variables which account for differences across countries such as the GDP per capita and being a democracy or not; 3) economic performance in the recent past, in particular the recent growth level. A complete list, along with definitions and sources of each variable is provided in Table A.2.

A significant innovation in our data concerns the definition of the dependent variable for government change. We employ two different dependent variables. The first one (GCHANGE) is the one used in previous studies and obtained from Jodice and Taylor (1983). This variable codes as one any regular or irregular (i.e., coup) transfer of executive power. ${ }^{14}$

In an attempt to eliminate from our dependent variable government changes which do not involve a substantial turnover of 
leadership, we have constructed a variable for major changes (MJCHANGE). This includes: i) all "irregular" transfers of power; ii) a subset of "regular" transfers which imply a change in the party, or coalition of parties in office. This change in the definition substantially reduces the number of "changes" in our dependent variable. The sample characteristics of our data are displayed in Table 1 .

A second innovation in our data set is our own construction of a variable for democratic institutions, DEMOC. This variable takes the value of one for countries with free competitive general elections with more than one party running; two for countries with some form of elections but with severe limits in the competitiveness of such ballots; three for countries in which their leaders are not elected. ${ }^{15}$

\subsection{The Specification of the Growth Equation}

The variables employed are described in Table A.2, separately for the cross-section data used in the single equation estimation, and the panel data used in the simultaneous equation estimation (differences between the two primarily arise from data availability).

Our specification draws heavily upon the recent growth literature. We include variables which proxy for the level of income and the level of human capital, as well as regional dummy variables. In the time series cross section specification we also control for the world business cycle by adding the weighted average of the lagged growth rate of the seven largest industrial economies and we control for "persistence" in growth by using the lagged dependent variable. 
In the joint estimation we use both economic and political variables to identify the growth and government change equations. In our base specification, the growth equation is identified by the enrollment ratio in primary school (EDUC). The government change equation is identified by the lagged dependent variable and by a dummy variable that indicates the occurrence of an executive adjustment (EXADJ), lagged one period. These three identifying assumptions imply one overidentifying restriction which can be tested. The test has a chi squared distribution with one degree of freedom; it essentially tests the difference between the reduced and structural form. A small value for the test statistic corresponds to a high $p$-value, which indicates the significance level of not rejecting the model.

\section{Results of the Single Equation Approach}

This section presents cross-sectional results which extend previous work by Barro (1989, 1991), Scully (1988), and Kormendi and Mcguire (1985). The joint endogeneity issue is addressed in the next section, where we estimate a simultaneous system; here, we first derive a measure of political instability and use it in cross-section growth regressions. As specified in (1) and (2) above, our procedure for constructing a measure of the probability of government change is to estimate a probit model of total government change on pooled time series and cross-country data. We then use the fitted values from this probit regression to derive the average predicted probability of a government change over the sample period for each country. The results of these probit regressions are presented in Table A.3 in the 
Appendix. ${ }^{16}$ The next step is to introduce our estimated measure of political instability from the probit regression in standard crosssectional regressions of the determinants of economic growth.

Before presenting these results, we show in column (1) of Table 2 a replication of Barro's regression for the average per capita growth rate of the 98 countries in the sample in the 1960-1985 period (for a list of countries see Table A-1). The results of this regression are familiar. Initial per capita income (GDP60) has a significant negative sign, confirming the hypothesis of conditional convergence; high economic growth is associated with high initial level of human capital (PRIM60 and SEC60); non-productive government spending (GOV) and distortions in the pricing of capital goods (PPI60DEV) lead to lower economic growth; and the two regional dummies for Latin America and Africa are significant with a negative sign. Finally, the coefficient on REVCOUP is negative and significant, indicating that violent government changes are associated with lower growth, while the assassination variable (ASSASS) has the right sign but is not statistically significant.

In column (2) of Table 2 we replace the REVCOUP and ASSASS variables with our measure of political instability (INS); this is the average predicted probability of a government change. The coefficient estimate is negative and significant at the 1 percent confidence level; after controlling for the other determinants of growth, per capita growth is lower in countries characterized by a higher degree of political instability. Column (3) shows that our measure of political instability remains significant even when the REVCOUP variable is 
included. Similar results (not displayed in the Table) are obtained when the ASSASS variable is also included.

Column (4) of Table 2 shows that a dummy for "democratic" regimes, DEMOCAV, is insignificant. Column (5) reports our results using a measure of political instability (MJINS) in which we consider only major changes of government. Thus, the dependent variable in the probit regression (in table A.4) used to obtain MJINS is MJCHANGE. This measure of instability is also significant. Furthermore, the coefficient is more than double in absolute value than that of the variable INS in column (2). As expected, major government changes have a more serious effect on growth.

Column (6) of Table 2 introduces a variable (PROT63) that is aimed at controlling for the orientation of the trade regime and the level of trade distortions (for the definition of this variable and further discussion of the impact of such variables on growth see Roubini and Sala-i-Martin (1991)). Our measure of political instability continues to be significant. PROT63 is defined in a way which implies that a negative coefficient on this variable indicates that more inward-oriented countries grow less. Additional regressions, not displayed, show that INS remains significant even when different measures of trade distortions are used.

In summary, this section has shown that the degree of political instability, as proxied by the probability of government change negatively affects per capita GDP growth. However, these singleequation regressions do not properly take into consideration the 
problem of joint endogeneity between growth and political instability. This issue is examined in the next section.

\section{Results of the Simultaneous Equations Approach}

Table 3 displays the results of the reduced form estimation both for the 1950-82 and 1960-82 samples. While the large sample includes more information, pre-1960 data are not available for most African countries and several Middle-Eastern and Latin American countries (see Table A.1). We report both estimates in order to emphasize that our results are robust to the sample choice.

Two issues are important to point out. First, the correlation between the two equations is estimated significantly, rejecting the null hypothesis that the shocks to growth and propensity of government change are uncorrelated. This implies that neither growth nor government change can be taken as predetermined, and hence estimation techniques that fail to account for the joint endogeneity will yield biased estimates. Second, the variables that instrument for government change (lagged EXADJ and lagged GCHANGE) are significant in the government change equation but not in the growth equation. Similarly EDUC is significant in the growth equation but not in the government change equation. These findings suggest that the variables considered are reasonable in instrumenting for growth and government change.

The corresponding structural form estimates are presented in Table 4. Inspection of these results suggests the following findings concerning the contemporaneous feedback effects: 1) The impact of 
political instability on growth, captured by the coefficient on GCHANGE in the growth equations, is negative. This result is statistically significant at high levels of confidence in the large sample, and statistically significant at lower levels of confidence in the small sample. 2) Current low growth does not appear to increase the propensity of a government change as can be seen in the parameter associated with the GROWTH variable in columns 2, and 4 .

Let us now turn to the other determinants of growth. The coefficients on the economic variables in the growth equation have the expected sign and are significant. Our proxy for lagged world growth (WGROWTH1) is significant and captures the effect of a "world business cycle". The level of education (EDUC) has a positive influence on growth. Finally, the region specific dummy variables which are typically found significant (and negative) in growth regressions, Latin America (LATIN) and Africa (AFRICA), are found negative here as well.

The results for the government change equation are also quite sensible. The occurrence of executive adjustments (EXADJ) increases the likelihood of a government change. Furthermore, government changes tend to be "persistent": a government change in the recent past increases the likelihood of another change. This result is consistent with the "coup trap" found by Londregan and Poole (1990): a history of frequent coups increase the likelihood of additional coups. Government change is less likely in Africa. Finally, low growth in the recent past does not seem to increase the probability of a government 
change. The coefficient on GROWTH(-1) in the government change equation is negative but insignificant.

The chi-squared test of our overidentifying restriction shows that in the large sample the model is not rejected at the .51 level of significance and in the small sample the model is not rejected at the .92 level of significance.

Table 5 displays the same two specifications, but now the dependent variable is MJCHANGE, i.e., "major government changes", instead of GCHANGE. The chi-squared tests of our overidentifying restriction do not reject our model at a high levels of significance as indicated the p-values of .88 and .53 for the large and small samples respectively. The coefficient of the propensity of "major government changes" on growth remains significant. The coefficient on the effect of growth on the propensity to observe major government changes is negative, but not statistically significant (though the " $\mathrm{t}$ " value reaches 1.38 in the the large sample).

In contrast to the results in Table 4, the coefficient on the Latin America dummy variable in the government change equation is positive and significant. This is not a surprising result once it is noted in Table 1 that while the frequency of GCHANGE for Latin America is actually lower than in the industrial and Asian countries, the frequency of MJCHANGE in Latin America is the highest in the world, almost double that in Asia and a third larger than in the industrial countries. These figures highlight how Latin America is a region with frequent major political changes and, as emphasized above, with low growth. This result supports the idea that what is particularly harmful to growth 
is polarization in the society and in the political arena leading to frequent substantial turnovers of political direction.

It is also worth emphasizing how it is likely to be the case that various events concerning political unrest such as government changes, attempted coups and executive adjustment are likely to be underreported in African countries. Note that Table 1 highlights how Africa has fewer government changes and executive adjustments than any other region in the world. Our result concerning the effect of political instability on growth would probably be strengthened by a correction of this underreporting bias. In fact, Africa is a region with low growth and an underestimated measure of political instability.

\section{Sensitivity Analysis and Discussion}

Our basic result that political instability is harmful to growth is robust to changes in the model specification discussed below.

No significant changes in the results are found when we add additional lags of EXADJUST and when we introduce the variable ATTEMPT, which measures unsuccessful attempts to change the government, including aborted coups, into the government change equations. We also considered an industrialized country dummy INDUST for the growth equation.

Specifications that incorporate the level of GDP (either GDP60 or GDP1, i.e., lagged level of GDP) are considered. The effect of political instability on growth remains statistically significant in all 
these specifications. However, the chi-square statistics are much larger than the ones found earlier, leading to a rejection of the model.

The effect of democratic institutions is investigated by adding the variable DEMOC in the growth equation. This specification of the model is rejected based on chi-squared tests, and the variable DEMOC is not found statistically significant.

As an alternative means of identifying the model the contemporaneous effects of growth on government changes is set equal to zero (note from Tables 3 and 4 that this parameter is not found statistically significant). The model is not rejected, but gives a much lower level of significance in comparison to specifications that do not impose this restriction. A consequence of this restriction is that coefficient on lagged GDP growth in the government change and major change equations becomes significant, indicating that low lagged growth increases the propensity to government changes.

Finally, Table 6 presents our base specification for the case in which the dependent variable for government changes is coup d'etat, as in Londregan and Poole (1990). We provide this result as a way of suggesting where the differences between the two sets of works might be arising form.

Unlike that study, we continue to find a negative and a statistically significant effect of the propensity of government change (now a coup detat) on growth. By focusing only on coup detat we in effect reduce the primary difference between these two sets of works to model specification (our general data base and econometric methodology and now the government change variable are almost 
identical). Our specifications differ from theirs primarily in that we use world growth, education, executive adjustments providing a richer set of predetermined variables. Based on a chi-squared test we do not reject the model at .3-.5 significance levels. (This compares favorably with Londregan and Poole, which does not reject at the .1 significance level.)

An interesting finding that emerges in Table 6 is that the contemporaneous growth has a significant impact on propensity of a coup detat. This result may indicate that when growth is low, one tends to observe "substantial" changes of political control rather than more reappointments of incumbents. This of course needs further investigation, as not all coup detats are substantial if it only involves a turnover of generals that is not associated with major political or economic uncertainty in the country.

\section{Concluding Remarks}

Political instability reduces growth. This finding is very robust: it has been obtained in a model in which several other economic determinants and "regional" factors affecting growth and political stability are accounted for. Democracies do not appear to show a different growth performance than non-democracies. Also, the occurrence of a government change increases the likelihood of subsequent changes, suggesting that political instability tends to be persistent.

Rather than reviewing in detail all our results, we conclude by highlighting several possible extensions of this paper. First, it is 
worthwhile to continue in our effort to distinguish cases of "major" government changes from "routine" turnovers of leadership with no significant changes in the ideological orientation of governments. Our efforts have been, thus far, reasonably successful in the sense that the results using our new variable improve, on some grounds, relative to those obtained with the Jodice and Taylor (1983) variable. Further research on this point is called for. For instance, one would like to address the following issue: in certain cases (Turkey in the late seventies is a good example), frequent coalition reshufflings are indicators of an underlying political unrests (which, in fact, culminated in a military coup in 1980). By disregarding such reshufflings, one underestimates the amount of political uncertainty. In other cases (Italy in the post Second War period is a good example), minor coalition reshufflings do not imply any significant amount of real political uncertainty and instability.

Second, one may try to classify the "ideological" direction of government changes and test for the effects of different government's ideology on economic growth. Such a classification on a "left" and "right" scale is reasonably easy for a subset of countries (for instance, OECD democracies), but much more problematic for other countries where religious, tribal or regional conflicts dominate the polity. ${ }^{17}$ An even more difficult but useful approach would be to attempt to measure the degree of ideological polarization of various parties and groups in different countries.

A third extension would be to include measures of income distribution. Alesina and Rodrik (1991) and Persson and Tabellini 
(1991) have found a negative relationship between income inequality and growth, particularly in democracies. Political unrest may also be influenced by inequality while economic development is bound to affect income distribution. Thus, the three variables, growth, political instability and income distribution are jointly endogenous. The difficulty in pursuing this extension is mostly due to the availability of reliable time series data on income distribution.

A fourth direction of research would be to pursue further the analysis of democracy and growth. As emphasized above, dictatorships are far from homogeneous. It would be quite interesting to engage in a disaggregate analysis of which politico-institutional characteristic of dictatorships make them more or less growth-enhancing. Some recent results by Poole and Londregan (1991b) suggest that this may in fact be a promising avenue of research. In a reduced form growth equation they find that the presence of "unconstitutional leaders" reduces growth. Their coding of "unconstitutional leaders" is probably close to capturing a subset of truly "kleptocratic" dictators.

A fifth direction of research is to study a "non linear" pattern of influence from economic growth to political stability and vice-versa. For instance, Huntington (1968) suggests that while at relatively a high level of income political stability and growth go hand in hand, periods of "take off", i.e., of exceptionally high growth, in middle-income countries may be associated with rapid social transformation and political unrest. More generally, the interaction between political stability, political change and growth may take different forms at different levels of development. 


\section{References}

Adelman, I. and C. Morris (1967), Society, Politics, and Economic Development, Baltimore: Johns Hopkins University Press.

Alesina, A. and D. Rodrik (1991), "Distributive Politics and Economic Growth," NBER Working Paper No. 3668.

Alesina, A., J. Londregan and H. Rosenthal (1990), "A Model of the Political Economy of the United States, "NBER Working Paper No. 3611.

Alesina A. and G. Tabellini (1990), "A Positive Theory of Fiscal Deficits and Debt," Review of Economic Structures, July.

Alesina A. and G. Tabellini (1989), "External Debt, Capital Flight and Political Risk," Journal of International Economics, November. Amemiya, T. (1978), "The Estimation of a Simultaneous Equation Generalized Probit Model," Econometrica.

Banks, Arthur, Political Handbook of the World, various issues.

Barro, R. (1989), "A Cross Country Study of Growth, Saving and Government," NBER WP No. 2855, February.

Barro, R. (1991), "Economic Growth in a Cross Section of Countries," Quarterly Journal of Economics, May.

Cukierman, A., S. Edwards and G. Tabellini (1992), "Seignorage and Political Instability," American Economic Review.

Dick, G.W. (1974), "Authoritarian versus Nonauthoritarian Approaches to Economic Development," Journal of Political Economy, 82: 817-827. 
Edwards, S. and G. Tabellini (1991), "Explaining Fiscal Policies and Inflation in Developing Countries," Journal of International Money and Finance, Vol. 10, March.

Efron, B. (1977), "Bootstrap Methods: Another Look at the Jackknife," The Annals of Statistics.

Fair, R. (1978), "The Effects of Economic Events on Votes for Presidents," The Review of Economics and Statistics, 60: 15972 .

Fiorina, M. (1981), Retrospective Voting in American National Elections, Yale University Press, New Haven, Conn.

Goldsmith, A. (1987), "Does Political Stability Hinder Economic Development?" Comparative Politics.

Goodrich, S. (1992), "Political Instability as a Determinant of U.S. Foreign Direct Investments," Harvard University Senior Thesis.

Grossman, H. (1991), "A General Equilibrium Theory of Insurrections," American Economic Review, forthcoming.

Heckman, J. (1978), "Dummy Endogenous Variables in a Simultaneous Equation System," Econometrica.

Huntington, S. (1968), Political Order in Changing Societies, Yale University Press, New Haven, Conn.

Huntington, S. and J. Dominguez (1975), "Political Development" in F. Greenstein and N. Polsby (eds.) Handbook of Political Science, Vol. 3 Macropolitical Theory, Reading, Mass.: Addison Wesley, 1-114. 
Jodice, D. and D.L. Taylor (1983), World Handbook of Social and Political Indicators, Yale University Press, New Haven, CT. Kormendi, R.C. and P.G. Mcguire (1985), "Macroeconomic Determinants of Growth: Cross-Country Evidence," Journal of Monetary Economics.

Kramer, G. (1971), "Short Term Fluctuations in U.S. Voting Behavior, 1896-1964, American Political Science Review, 65: 131-143.

Londregan, J. and K. Poole (1990), "Poverty, The Coup Trap, and The Seizure of Executive Power," World Politics, January. and (1991a), "The Seizure of Executive Power and Economic Growth: Some Additional Evidence," May. and (1991b), "Leadership Turnover and Unconstitutional Rule," unpublished.

Marsh, R. (1979), "Does Democracy Hinder Economic Development in the Latecomer Developing Nations?" Comparative Social Research, 2: 215-249.

Murphy, K., A. Shleifer and Vishny (1991), "The Allocation of Talent: Implications for Growth," Quarterly Journal of Economics, May.

Newey, W.K. (1987) "Efficient Estimation of Limited Dependent Variable Models with Endogenous Explanatory Variables," Journal of Econometrics. 
Olson, M. (1982), The Rise and Decline of Nations: Economic Growth, Stagflation and Social Rigidities, New Haven: Yale University Press.

Özler, S. and G. Tabellini (1991), "External Debt and Political Instability," NBER Working Paper, July.

Persson, T. and G. Tabellini (1991), "Is Inequality Harmful to Growth?," NBER Working Paper.

Powel, G. Bingham (1982), Contemporary Democracies, Harvard University Press,

Cambridge.

Robertson (1983), "Inflation, Unemployment and Government Collapse," Comparative Political Studies, January.

Rodrik, D. (1989), "Policy Uncertainty and Private Investment in Developing Countries," NBER Working Paper No. 2999.

Roubini, N. (1990), "The Interaction between Macroeconomic Performance and Political Structures and Institutions: The Political Economy of Poverty, Growth and Development," background paper for the 1990 World Development Report, World Bank, February.

Roubini, N. (1991), "Economic and Political Determinants of Budget Deficits in Developing Countries," Journal of International Money and Finance, Vol. 10, March.

Roubini, N. and J. Sachs (1989a), "Political and Economic Determinants of Budget Deficits in the Industrial Economies," European Economic Review, May. 
Roubini, N. and J. Sachs (1989b), "Government Spending and Budget Deficits in the Industrial Economies," Economic Policy, No. 8, Spring.

Roubini and X. Sala-i-Martin (1991), "The Relation between Trade Regime, Financial Development and Economic Growth," mimeo, Yale University, February.

Scully, G.W. (1989), "The Institutional Framework and Economic Development," Journal of Political Economy.

Summers, R. and A. Heston (1988), "A New Set of International Comparisons of Real Product and Price Levels: Estimates for 130 Countries," Review of Income and Wealth.

Tabellini, G. and A. Alesina (1990), "Voting on the Budget Deficits," American Economic Review, March.

Terrones, M. (1989), "Influence Activities and Economic Growth," unpublished.

Weede, E. (1983), "The Impact of Democracy on Economic Growth: Some Evidence from Cross-National Analysis, "Kyklos, 36, 2140. 


\section{ENDNOTES}

1. There exists, of course, a vast literature in political science concerning this issue. Two of the most influential contributions are Huntington (1968) and Huntington and Dominguez (1975).

2. Alesina, Londregan and Rosenthal (1990) also address this problem of joint endogeneity of government changes and growth for the U.S.

3. See Rodrik (1989) for a study of the effects of policy uncertainty on private investment in developing countries.

4. Goodrich (1992) finds that foreign direct investments have been negatively affected by a high degree of political instability in a large sample of LDC countries. Her definition of "political instability" is the same as that of the present paper.

5. Empirical evidence on the effects of political instability on macro variables 
such as seigniorage taxation, inflation rates, budget deficits and external debt accumulation is provided in Cukierman, Edwards and Tabellini (1990), Edwards and Tabellini (1991), Özler and Tabellini (1991), Roubini (1991), Roubini and Sachs $(1989 a, 1989 b)$.

6. This literature also incorporates the idea that the likelihood of a government change has a larger effect on the degree of uncertainty in the economic environment, the higher the degree of "political polarization" in society. The latter is defined as the difference in the preferences over economic outcomes of different groups or parties competing for office. The propensity of a government change is not likely to have much effect on economic decisions if the next government is expected to follow similar policies to the current one. Thus, the propensity of a government change should have stronger 
effects on growth, the higher is the level of polarization.

7. For instance, Kramer (1971), Fair (1978), Robertson (1983), Fiorina (1981), and Alesina, Londregan and Rosenthal (1990) .

8. This "incompatibility hypothesis" has been formulated in a number of ways: see Huntington and Nelson (1976), Kahn (1979) and Olson (1982).

9. A very short and very incomplete list would include Amin of Uganda, Bokassa in the Central African Republic, the Somoza and Duvalier dynasties in Nicaragua and Haiti, the generals of Bolivia and the rulers of Guatemala.

10. See Adelman and Morris (1967), Huntington and Dominguez (1975), Marsh (1979) .

11. These studies include Dick (1974), Goldsmith (1987) and the recent 
systematic work by Weede (1983) on a sample of 94 countries.

12. However, this problem does not invalidate the t-statistics for the null hypothesis that the estimated coefficient of the instability is zero (Pagan (1984)).

13. The extent of the time period for our sample is limited by the availability of data on various indicators of political unrest; in particular, for almost half of the countries, data are available from 1960 only.

14. We have checked this variable by going back to original sources and corrected coding errors mistakes. This is available upon request.

15. An example of a country coded 2 is Mexico where elections were regularly held but with a one party rule and with widespread allegations of electoral fraud. In general, when judgement calls had to be 
made we chose to be "conservative" in what we defined a "democracy".

16. As expected, political factors such as past government change, attempted coups and executive adjustment affect the probability of government change. We did not include lagged growth in the probit regressions since the generated probability estimate is used as an independent variable in regressions where growth is the dependent variable. If we add lagged growth in the probit regression, this variable is significant and our results improve slightly.

17. See Powel (1982) for a discussion of classifications that consider class, religious and ethnic dimensions at various levels of development. 
Table 1

Sample Means of the Data: $1960-82 *$

(Standard deviations in parentheses)

\begin{tabular}{lcccccc}
\hline \hline & ALL & LATIN & AFRICA & ASIA & INDUST & OTHER \\
\hline GCHANGE & .28 & .29 & .21 & .30 & .39 & .37 \\
& $(.45)$ & $(.45)$ & $(.41)$ & $(.46)$ & $(.49)$ & $(.48)$ \\
MJCHANGE & .11 & .16 & .11 & .07 & .12 & .16 \\
COUP & $(.32)$ & $(.36)$ & $(.31)$ & $(.25)$ & $(.32)$ & $(.37)$ \\
& .048 & .078 & .057 & .040 & .00 & .058 \\
EXADJ & $(.21)$ & $(.27)$ & $(.23)$ & $(.20)$ & $(.00)$ & $(.23)$ \\
& .49 & .49 & .42 & .54 & .53 & .57 \\
DEMOC & $(.50)$ & $(.50)$ & $(.49)$ & $(.50)$ & $(.50)$ & $(.50)$ \\
& 2.24 & 2.18 & 2.83 & 2.33 & 1.07 & 2.23 \\
GROWTH & $(.93)$ & $(.92)$ & $(.50)$ & $(.89)$ & $(.37)$ & $(.91)$ \\
& .024 & .022 & .015 & .033 & .029 & .041 \\
WGROWTH & $(.069)$ & $(.065)$ & $(.084)$ & $(.068)$ & $(.035)$ & $(.060)$ \\
& .029 & - & - & - & - & - \\
EDUC & $(.019)$ & & & & & \\
& .827 & .963 & .625 & .826 & 1.020 & .995 \\
GDP60 & $(.30)$ & $(.18)$ & $(.33)$ & $(.25)$ & $(.17)$ & $(.22)$ \\
& 2625 & 2170 & 881 & 3379 & 6021 & 1879 \\
GDP & $(4202)$ & $(1003)$ & $(499)$ & $(8521)$ & $(1801)$ & $(163)$ \\
& 3551 & 3021 & 1152 & 3685 & 8754 & 3395 \\
Countries & $(3919)$ & $(1618)$ & $(874)$ & $(5771)$ & $(2484)$ & $(1155)$ \\
Observations & 113 & 259 & 41 & 21 & 21 & 6 \\
(1960-82) & & 552 & 943 & 476 & 483 & 138 \\
Observations & 3259 & 759 & 1051 & 572 & 693 & 184 \\
(1950-82) & & & & & & \\
\hline \hline
\end{tabular}

*Region breakdowns use the IMF coding system. Hence, the "other" category refers to nonindustrialized European countries. 
Table 2

Cross-Section Regressions on Growth

Dependent Variable: Average Per Capita Growth 1960-85 (t-statistics in parentheses)

\begin{tabular}{|c|c|c|c|c|c|c|}
\hline $\begin{array}{l}\text { Explanatory } \\
\text { Variables } \\
\end{array}$ & (1) & (2) & (3) & (4) & (5) & (6) \\
\hline Constant & $\begin{array}{r}0.035 \\
(4.87)\end{array}$ & $\begin{array}{l}0.066 \\
(4.44)\end{array}$ & $\begin{array}{c}0.062 \\
(4.52)\end{array}$ & $\begin{array}{c}0.031 \\
(2.84)\end{array}$ & $\begin{array}{r}0.054 \\
(4.19)\end{array}$ & $\begin{array}{l}0.108 \\
(7.25)\end{array}$ \\
\hline GDP60 & $\begin{array}{r}-0.007 \\
(-7.08)\end{array}$ & $\begin{array}{c}-0.006 \\
(-6.68)\end{array}$ & $\begin{array}{l}-0.006 \\
(-7.26)\end{array}$ & $\begin{array}{c}-0.006 \\
(-6.02)\end{array}$ & $\begin{array}{l}-0.006 \\
(-6.71)\end{array}$ & $\begin{array}{r}-0.008 \\
(-10.07)\end{array}$ \\
\hline SEC60 & $\begin{array}{r}0.011 \\
(1.40)\end{array}$ & $\begin{array}{l}0.015 \\
(1.75)\end{array}$ & $\begin{array}{r}0.014 \\
(1.69)\end{array}$ & $\begin{array}{c}0.010 \\
(1.01)\end{array}$ & $\begin{array}{r}0.015 \\
(1.86)\end{array}$ & $\begin{array}{c}0.014 \\
(2.50)\end{array}$ \\
\hline PRIM60 & $\begin{array}{c}0.026 \\
(4.06)\end{array}$ & $\begin{array}{c}0.031 \\
(5.47)\end{array}$ & $\begin{array}{r}0.028 \\
(4.60)\end{array}$ & $\begin{array}{c}0.030 \\
(4.75)\end{array}$ & $\begin{array}{c}0.028 \\
(4.61)\end{array}$ & $\begin{array}{c}0.011 \\
(1.32)\end{array}$ \\
\hline GOV & $\begin{array}{c}-0.100 \\
(-3.52)\end{array}$ & $\begin{array}{c}-0.093 \\
(-3.37)\end{array}$ & $\begin{array}{r}-0.101 \\
(-3.70)\end{array}$ & $\begin{array}{c}-0.083 \\
(-2.83)\end{array}$ & $\begin{array}{r}-0.090 \\
(-3.30)\end{array}$ & $\begin{array}{c}-0.082 \\
(-2.54)\end{array}$ \\
\hline PPI60DEV & $\begin{array}{c}-0.014 \\
(-2.89)\end{array}$ & $\begin{array}{c}-0.017 \\
(-3.61)\end{array}$ & $\begin{array}{r}-0.013 \\
(-3.06)\end{array}$ & $\begin{array}{c}-0.018 \\
(-3.52)\end{array}$ & $\begin{array}{l}-0.014 \\
(-2.55)\end{array}$ & $\begin{array}{r}-0.008 \\
(-0.59)\end{array}$ \\
\hline LATIN & $\begin{array}{c}-0.014 \\
(-4.34)\end{array}$ & $\begin{array}{r}-0.021 \\
(-5.98)\end{array}$ & $\begin{array}{r}-0.019 \\
(-4.92)\end{array}$ & $\begin{array}{r}-0.016 \\
(-5.12)\end{array}$ & $\begin{array}{r}-0.001 \\
(-0.22)\end{array}$ & $\begin{array}{r}-0.014 \\
(-2.95)\end{array}$ \\
\hline AFRICA & $\begin{array}{c}-0.012 \\
(-2.78)\end{array}$ & $\begin{array}{c}-0.024 \\
(-4.10)\end{array}$ & $\begin{array}{r}-0.021 \\
(-3.86)\end{array}$ & $\begin{array}{r}-0.011 \\
(-2.42)\end{array}$ & $\begin{array}{l}-0.010 \\
(-2.13)\end{array}$ & $\begin{array}{l}-0.027 \\
(-4.12)\end{array}$ \\
\hline REVCOUP & $\begin{array}{c}-0.016 \\
(-2.29)\end{array}$ & - & $\begin{array}{r}-0.014 \\
(-2.07)\end{array}$ & - & - & - \\
\hline ASSASS & $\begin{array}{r}-0.002 \\
(-1.34)\end{array}$ & - & - & - & - & - \\
\hline INS & - & $\begin{array}{c}-0.112 \\
(-2.98)\end{array}$ & $\begin{array}{r}-0.090 \\
(-2.36)\end{array}$ & - & - & $\begin{array}{r}-0.127 \\
(-2.94)\end{array}$ \\
\hline INSMJ & - & - & - & - & $\begin{array}{c}-0.26 \\
(-2.38)\end{array}$ & - \\
\hline PROT63 & - & - & - & - & - & $\begin{array}{r}-0.010 \\
(-4.55)\end{array}$ \\
\hline DEMOCAV & - & - & - & $\begin{array}{l}-0.001 \\
(0.40) \\
\end{array}$ & - & - \\
\hline Sample Size & 98 & 98 & 98 & 98 & 98 & 59 \\
\hline Adjusted $R^{2}$ & 0.58 & 0.58 & 0.60 & 0.55 & 0.57 & 0.80 \\
\hline St. Error & 0.012 & 0.012 & 0.012 & 0.012 & 0.012 & 0.009 \\
\hline
\end{tabular}


Table 3

Reduced Form of Growth and Government Changes:

Specification of Table 2

( $\mathrm{t}$-statistics in parentheses)

\begin{tabular}{|c|c|c|c|c|}
\hline & \multicolumn{2}{|c|}{ Sample 1950-82 } & \multicolumn{2}{|c|}{ Sample $1960-82$} \\
\hline & $\begin{array}{l}\text { Growth } \\
\text { Equation } \\
\text { (1) }\end{array}$ & $\begin{array}{l}\text { Gov. } \\
\text { Change } \\
\text { Equation } \\
(2)\end{array}$ & $\begin{array}{l}\text { Growth } \\
\text { Equation } \\
\text { (3) }\end{array}$ & $\begin{array}{c}\text { Gov. } \\
\text { Change } \\
\text { Equation } \\
(4) \\
\end{array}$ \\
\hline CONSTANT & $\begin{array}{l}0.0050 \\
(0.90)\end{array}$ & $\begin{array}{r}-0.583 \\
(-11.22)\end{array}$ & $\begin{array}{l}0.0009 \\
(0.15)\end{array}$ & $\begin{array}{r}-0.599 \\
(-10.52)\end{array}$ \\
\hline GROWTH(-1) & $\begin{array}{c}0.123 \\
(6.72)\end{array}$ & $\begin{array}{l}-1.262 \\
(-7.25)\end{array}$ & $\begin{array}{c}0.135 \\
(6.66)\end{array}$ & $\begin{array}{l}-1.556 \\
(-8.44)\end{array}$ \\
\hline WGROWTH(-1) & $\begin{array}{r}0.411 \\
(6.29)\end{array}$ & $\begin{array}{l}1.583 \\
(2.61)\end{array}$ & $\begin{array}{r}0.525 \\
(6.90)\end{array}$ & $\begin{array}{l}2.126 \\
(3.15)\end{array}$ \\
\hline LATIN & $\begin{array}{r}-0.010 \\
(-3.48)\end{array}$ & $\begin{array}{c}-0.122 \\
(-4.52)\end{array}$ & $\begin{array}{l}-0.0099 \\
(-2.79)\end{array}$ & $\begin{array}{l}-0.146 \\
(-4.85)\end{array}$ \\
\hline AFRICA & $\begin{array}{r}-0.011 \\
(-3.52)\end{array}$ & $\begin{array}{r}-0.410 \\
(-13.48)\end{array}$ & $\begin{array}{r}-0.011 \\
(-3.02)\end{array}$ & $\begin{array}{r}-0.439 \\
(-13.79)\end{array}$ \\
\hline EDUC & $\begin{array}{r}0.013 \\
(2.77)\end{array}$ & $\begin{array}{c}0.02 \\
(0.54)\end{array}$ & $\begin{array}{c}0.014 \\
(2.57)\end{array}$ & $\begin{array}{c}-0.0007 \\
(-0.015)\end{array}$ \\
\hline $\operatorname{EXADJ}(-1)$ & $\begin{array}{r}-0.001 \\
(-0.52)\end{array}$ & $\begin{array}{l}(0.119) \\
(5.42)\end{array}$ & $\begin{array}{l}-0.0021 \\
(-0.78)\end{array}$ & $\begin{array}{r}0.160 \\
(6.74)\end{array}$ \\
\hline GCHANGE $(-1)$ & $\begin{array}{c}-0.0048 \\
(-1.83) \\
\end{array}$ & $\begin{array}{r}0.292 \\
(12.49) \\
\end{array}$ & $\begin{array}{l}-0.0041 \\
(-1.36) \\
\end{array}$ & $\begin{array}{r}0.282 \\
(10.99) \\
\end{array}$ \\
\hline \multicolumn{2}{|c|}{$R^{2}$ of growth equation } & .045 & \multicolumn{2}{|c|}{.051} \\
\hline \multicolumn{5}{|l|}{ Cases correct for } \\
\hline $\begin{array}{l}\text { correlation between } \\
\text { shocks to growth } \\
\text { and govt. changes }\end{array}$ & & $\begin{array}{l}-.108 \\
(.026)\end{array}$ & \multicolumn{2}{|c|}{$\begin{array}{l}-.135 \\
(.029)\end{array}$} \\
\hline
\end{tabular}


Table 4

Joint Estimation of Growth and Government Changes: Base Specification ( $t$-statistics in parentheses)

\begin{tabular}{|c|c|c|c|c|}
\hline & \multicolumn{2}{|c|}{ Sample 1950-82 } & \multicolumn{2}{|c|}{ Sample $1960-82$} \\
\hline & $\begin{array}{l}\text { Growth } \\
\text { Equation } \\
\text { (1) }\end{array}$ & $\begin{array}{l}\text { Gov. } \\
\text { Change } \\
\text { Equation } \\
(2)\end{array}$ & $\begin{array}{l}\text { Growth } \\
\text { Equation } \\
(3)\end{array}$ & $\begin{array}{l}\text { Gov. } \\
\text { Change } \\
\text { Equation } \\
\text { (4) }\end{array}$ \\
\hline GROWTH & & $\begin{array}{c}1.720 \\
(0.21)\end{array}$ & - & $\begin{array}{c}-0.126 \\
(-0.016)\end{array}$ \\
\hline GCHANGE & $\begin{array}{c}-0.014 \\
(-2.85)\end{array}$ & - & $\begin{array}{c}-0.014 \\
(-1.60)\end{array}$ & - \\
\hline CONSTANT & $\begin{array}{c}-0.003 \\
(-0.43)\end{array}$ & $\begin{array}{r}-0.593 \\
(-7.58)\end{array}$ & $\begin{array}{l}-0.008 \\
(-1.00)\end{array}$ & $\begin{array}{r}-0.600 \\
(-4.86)\end{array}$ \\
\hline GROWTH(-1) & $\begin{array}{l}0.105 \\
(0.77)\end{array}$ & $\begin{array}{l}-1.462 \\
(-0.72)\end{array}$ & $\begin{array}{c}0.112 \\
(0.89)\end{array}$ & $\begin{array}{l}-1.538 \\
(-1.23)\end{array}$ \\
\hline WGROWTH(-1) & $\begin{array}{c}0.433 \\
(6.19)\end{array}$ & $\begin{array}{r}0.871 \\
(0.20)\end{array}$ & $\begin{array}{c}0.556 \\
(6.71)\end{array}$ & $\begin{array}{l}2.195 \\
(0.41)\end{array}$ \\
\hline LATIN & $\begin{array}{c}-0.012 \\
(-4.35)\end{array}$ & $\begin{array}{c}-0.103 \\
(-1.16)\end{array}$ & $\begin{array}{r}-0.012 \\
(-3.60)\end{array}$ & $\begin{array}{r}-0.147 \\
(-1.68)\end{array}$ \\
\hline AFRICA & $\begin{array}{l}-0.017 \\
(-2.75)\end{array}$ & $\begin{array}{c}-0.391 \\
(-2.66)\end{array}$ & $\begin{array}{r}-0.017 \\
(-2.83)\end{array}$ & $\begin{array}{r}-0.440 \\
(-5.52)\end{array}$ \\
\hline EDUC & $\begin{array}{l}0.014 \\
(2.52)\end{array}$ & - & $\begin{array}{c}0.014 \\
(2.40)\end{array}$ & - \\
\hline $\operatorname{EXADJ}(-1)$ & - & $\begin{array}{l}(0.122) \\
(2.57)\end{array}$ & - & $\begin{array}{r}0.160 \\
(3.29)\end{array}$ \\
\hline GCHANGE(-1) & - & $\begin{array}{c}0.298 \\
(2.44)\end{array}$ & - & $\begin{array}{c}0.282 \\
(4.74)\end{array}$ \\
\hline
\end{tabular}

$x^{2}$ test of the 1 over-

identifying restriction

0.427

0.0108

p-value

0.513

0.917 
Table 5

Joint Estimation of Growth and Major Changes: Base Specification (t-statistics in parentheses)

\begin{tabular}{|c|c|c|c|c|}
\hline & \multicolumn{2}{|c|}{ Sample $1950-82$} & \multicolumn{2}{|c|}{ Sample $1960-82$} \\
\hline & $\begin{array}{l}\text { Growth } \\
\text { Equation } \\
\text { (1) }\end{array}$ & $\begin{array}{c}\text { Major } \\
\text { Change } \\
\text { Equation } \\
\text { (2) }\end{array}$ & $\begin{array}{c}\text { Growth } \\
\text { Equation } \\
\text { (3) }\end{array}$ & $\begin{array}{c}\text { Major } \\
\text { Change } \\
\text { Equation } \\
(4) \\
\end{array}$ \\
\hline GROWTH & - & $\begin{array}{l}-7.624 \\
(-1.38)\end{array}$ & - & $\begin{array}{r}-4.192 \\
(-0.74)\end{array}$ \\
\hline MAJCHANGE & $\begin{array}{l}-0.00641 \\
(-2.93)\end{array}$ & - & $\begin{array}{l}-0.0121 \\
(-2.59)\end{array}$ & - \\
\hline CONSTANT & $\begin{array}{l}-0.0049 \\
(-0.79)\end{array}$ & $\begin{array}{l}-1.313 \\
(-9.93)\end{array}$ & $\begin{array}{l}-0.016 \\
(-1.90)\end{array}$ & $\begin{array}{r}-1.340 \\
(-8.91)\end{array}$ \\
\hline GROWTH(-1) & $\begin{array}{r}0.115 \\
(0.22)\end{array}$ & $\begin{array}{c}-0.537 \\
(-0.041)\end{array}$ & $\begin{array}{r}0.111 \\
(0.34)\end{array}$ & $\begin{array}{l}-1.251 \\
(-0.16)\end{array}$ \\
\hline WGROWTH(-1) & $\begin{array}{r}0.414 \\
(5.93)\end{array}$ & $\begin{array}{r}3.511 \\
(1.03)\end{array}$ & $\begin{array}{r}0.524 \\
(6.31)\end{array}$ & $\begin{array}{c}2.307 \\
(0.56)\end{array}$ \\
\hline LATIN & $\begin{array}{l}-0.0085 \\
(-3.10)\end{array}$ & $\begin{array}{l}0.171 \\
(2.17)\end{array}$ & $\begin{array}{l}-0.0064 \\
(-2.00)\end{array}$ & $\begin{array}{l}0.220 \\
(2.48)\end{array}$ \\
\hline AFRICA & $\begin{array}{r}-0.011 \\
(-0.49)\end{array}$ & $\begin{array}{l}-0.116 \\
(-0.19)\end{array}$ & $\begin{array}{l}-0.011 \\
(-0.75)\end{array}$ & $\begin{array}{r}-0.087 \\
(-0.22)\end{array}$ \\
\hline EDUC & $\begin{array}{r}0.012 \\
(5.04)\end{array}$ & - & $\begin{array}{r}0.013 \\
(4.42)\end{array}$ & - \\
\hline $\operatorname{EXADJ}(-1)$ & - & $\begin{array}{l}(0.231) \\
(3.74)\end{array}$ & - & $\begin{array}{r}0.244 \\
(3.79)\end{array}$ \\
\hline MAJCHNG(-1) & - & $\begin{array}{c}0.173 \\
(0.35)\end{array}$ & - & $\begin{array}{l}0.187 \\
(0.65)\end{array}$ \\
\hline $\begin{array}{l}\chi^{2} \text { test of the } 1 \text { ov } \\
\text { identifying restrict }\end{array}$ & & & & \\
\hline $\mathrm{p}$-value & & & & \\
\hline
\end{tabular}


Table 6

Joint Estimation of Growth and Coups: Base Specification (t-statistics in parentheses)

\begin{tabular}{|c|c|c|c|c|}
\hline & \multicolumn{2}{|c|}{ Sample $1950-82$} & \multicolumn{2}{|c|}{ Sample 1960-82 } \\
\hline & $\begin{array}{l}\text { Growth } \\
\text { Equation } \\
\text { (1) }\end{array}$ & $\begin{array}{l}\text { Coup } \\
\text { Equation } \\
(2)\end{array}$ & $\begin{array}{l}\text { Growth } \\
\text { Equation } \\
\text { (3) }\end{array}$ & $\begin{array}{c}\text { Coup } \\
\text { Equation } \\
\text { (4) }\end{array}$ \\
\hline GROWTH & - & $\begin{array}{c}-45.048 \\
(-3.70)\end{array}$ & - & $\begin{array}{l}-39.93 \\
(-2.99)\end{array}$ \\
\hline COUP & $\begin{array}{c}-0.0061 \\
(-11.35)\end{array}$ & - & $\begin{array}{c}-0.0092 \\
(-12.69)\end{array}$ & - \\
\hline CONSTANT & $\begin{array}{l}-0.0070 \\
(-1.66)\end{array}$ & $\begin{array}{l}-1.532 \\
(-8.81)\end{array}$ & $\begin{array}{l}-0.0159 \\
(-3.33)\end{array}$ & $\begin{array}{l}-1.718 \\
(-9.77)\end{array}$ \\
\hline GROWTH(-1) & $\begin{array}{c}0.118 \\
(0.038)\end{array}$ & $\begin{array}{c}4.465 \\
(0.043)\end{array}$ & $\begin{array}{c}0.115 \\
(0.035)\end{array}$ & $\begin{array}{c}4.005 \\
(0.037)\end{array}$ \\
\hline WGROWTH(-1) & $\begin{array}{c}0.418 \\
(5.98)\end{array}$ & $\begin{array}{l}19.60 \\
(3.77)\end{array}$ & $\begin{array}{r}0.536 \\
(6.45)\end{array}$ & $\begin{array}{l}22.30 \\
(3.13)\end{array}$ \\
\hline LATIN & $\begin{array}{l}-0.0068 \\
(-2.49)\end{array}$ & $\begin{array}{c}0.100 \\
(0.62)\end{array}$ & $\begin{array}{l}-0.0044 \\
(-1.40)\end{array}$ & $\begin{array}{c}0.189 \\
(1.03)\end{array}$ \\
\hline AFRICA & $\begin{array}{l}-0.0093 \\
(-0.074)\end{array}$ & $\begin{array}{c}-0.239 \\
(-0.049)\end{array}$ & $\begin{array}{r}-0.0081 \\
(-0.063)\end{array}$ & $\begin{array}{l}-0.165 \\
(-0.033)\end{array}$ \\
\hline EDUC & $\begin{array}{c}0.0094 \\
(1.77)\end{array}$ & - & $\begin{array}{l}0.0088 \\
(1.38)\end{array}$ & - \\
\hline $\operatorname{EXADJ}(-1)$ & - & $\begin{array}{l}(0.227) \\
(2.60)\end{array}$ & - & $\begin{array}{l}0.197 \\
(1.96)\end{array}$ \\
\hline $\operatorname{COUP}(-1)$ & - & $\begin{array}{c}0.559 \\
(0.14)\end{array}$ & - & $\begin{array}{c}0.652 \\
(0.18)\end{array}$ \\
\hline $\begin{array}{l}\chi^{2} \text { test of the } 1 \text { over } \\
\text { identifying restrictio }\end{array}$ & \multicolumn{2}{|c|}{0.365} & \multicolumn{2}{|c|}{1.0337} \\
\hline$p$-value & \multicolumn{2}{|c|}{0.546} & \multicolumn{2}{|c|}{0.309} \\
\hline
\end{tabular}


Appendix

Countries, Variables and Sources

Table A.1

Countries and Sample Period ${ }^{(+)}$

\begin{tabular}{|c|c|c|}
\hline $\begin{array}{l}\text { Sample } 1950-82 \\
\text { (60 Countries) }\end{array}$ & $\begin{array}{l}\text { Sample } 1960-82 \\
\text { (39 Countries) }\end{array}$ & $\begin{array}{l}\text { Other } \\
\text { (14 Countries) }\end{array}$ \\
\hline U.S.* & Yugoslavia* & Malta* (1954) \\
\hline U.K.* & Haiti* & Jamaica* (1953) \\
\hline Austria* & Barbados* & Israel* (1953) \\
\hline Belgium* & Surinam & Jordan* (1954) \\
\hline Denmark* & Kuwait & Bangladesh* (1959) \\
\hline France* & Saudi Arabia & Indonesia* (1962) \\
\hline Germany* & Syria & S. Korea* (1953) \\
\hline Italy* & Hong Kong* & Malaysia* (1955) \\
\hline Luxembourg* & Nepal* & Benin (1959) \\
\hline Netherlands* & Singapore* & Ghana (1955) \\
\hline Norway* & Algeria* & Malawi* (1954) \\
\hline Sweden* & Botswana* & Zimbabwe* (1954) \\
\hline Switzerland* & Burundi* & Sudan" (1955) \\
\hline Canada* & Cameroon* & Zambia* (1955) \\
\hline Japan* & Cape Verde & \\
\hline Finland* & Central African Republic & \\
\hline Greece* & Chad & \\
\hline Iceland* & Congo & \\
\hline Ireland* & Gabon* & \\
\hline Portugal* & Gambia* & \\
\hline Spain* & Guinea-Bissau & \\
\hline Turkey* & Ivory Coast* & \\
\hline Australia* & Lesotho & \\
\hline New Zealand* & Liberia* & \\
\hline South Africa* & Madagascar* & \\
\hline Argentina* & Mali & \\
\hline Bolivia* & Mauritania & \\
\hline Brazil* & Mozambique & \\
\hline Chile* & Niger & \\
\hline Colombia* & Rwanda* & \\
\hline Costa Rica* & Senegal* & \\
\hline Dominican Republic* & Sierre Leone* & \\
\hline Ecuador* & Somalia & \\
\hline El Salvador* & Swaziland* & \\
\hline Guatemala* & Tanzania* & \\
\hline Honduras* & Togo* & \\
\hline Mexico* & Tunisia* & \\
\hline Nicaragua* & Fiji* & \\
\hline Panama* & Papua New Guinea* & \\
\hline
\end{tabular}




\section{Paraguay* \\ Peru* \\ Uruguay* \\ Venezuela* \\ Guyana* \\ Trinidad* \\ Cyprus* \\ Egypt* \\ Sri Lanka* \\ Taiwan* \\ India* \\ Pakistan* \\ Philippines* \\ Thailand* \\ Zaire* \\ Ethiopia* \\ Kenya* \\ Mauritius* \\ Morocco* \\ Nigeria* \\ Uganda*}

(+) A $A^{*}$ next to a country indicates that it is one of the 98 observations of Table 2.

The end of the sample period is 1982 for all countries, except South Korea and Hong Kong, for which political data is available only through 1977 .

** The date next to each country in this group indicates the beginning of the sample for which data are available. 
Table A.2

\section{Variables Used in Government Change Equations}

\section{Dependent variables}

GCHANGE = Government change. Dummy variable which takes a value of 1 for the years in which there is either a coup or a regular government transfer, and a value of 0 otherwise. [Source: Jodice and Taylor (1983)]. We found several coding errors in this variable which we adjusted.

MJCHANGE = Major government change. Dummy variable which takes a value of 1 for the years in which there is either a coup or a major regular government transfer, and a value of 0 otherwise. [Source: Authors' construction from Banks, various issues].

\section{Explanatory variables}

Political variables:

$\mathrm{DEMOC}=$ Democracy variable taking value 1 for democratic regimes, 2 for regimes mixing democratic and authoritarian features, 3 for authoritarian regimes. [Source: Authors' construction from Banks, various issues].

EXADJ = Dummy variable which takes the value of 1 in years in which there is a change in the composition of the executive not resulting in government transfers. [Source: Jodice and Taylor (1983)].

ATTEMPT $=$ Dummy variable which takes the value of 1 in years in which there was an unsuccessful attempt at changing the government. Includes failed coups. [Source: Jodice and Taylor (1983)].

Economic variables:

GROWTH $=$ Annual rate of growth of per capita GDP. [Source: Constructed from Summers and Heston (1991)].

GDP = Log of real per capita GDP level (adjusted for terms of trade). [Source: Summers and Heston (1991)]

Regional dummy variables:

LATIN = Dummy variable for South America and Latin America.

AFRICA $=$ Dummy variable for Africa. 
Table A.2

\section{Variable Definitions for Economic Growth Equations}

\section{Cross section regressions}

Dependent variable:

GR6085 = Average annual rate of growth of per capita GDP in 1960-1985 period. [Source: Summers and Heston (1988)].

Explanatory variables:

Political variables

INS = Average probability of government change for each country. Constructed from the probit model of government change shown in A.3.

INSMJ = Average probability of major government change for each country. Constructed from the probit model of major government change (MJCHANGE) described in A.3.

DEMOCAV = Country average of the democracy dummy variable (DEMOC); see Table A.1.

REVCOUP $=$ Number of revolutions and coups per year (1960-85 or subsample). [Source: Barro-Wolf data set].

ASSASS = Number of assassinations per million population per year [Source: Barro-Wolf data set].

Economic variables:

GDP60 = Log of per capita GDP level in 1960. [Source: Summers and Heston (1991)].

PRIM60 = Primary school enrollment rate, 1960. [Source: Summers and Heston (1991)].

SEC60 = Secondary school enrollment rate, 1960. [Source: Summers and Heston (1988)].

GOV = Average of the real government consumption (exclusive of defense and education) to Real GDP. [Source: Barro and Wolf data set].

PPI60DEV $=$ Deviation of the 1960 PPP value of the investment deflator from the sample mean. [Source: Barro and Wolf data set].

PROT63 = Dummy variable taking values $1,2,3,4$ based upon the outward/inward orientation of the trade regime, for the period 1963-73. [Source: World Bank 1987 Development Report and additional information collected by Roubini and Sala-i-Martin (1991). 
Regional dummy variables:

LATIN, AFRICA, see above.

\section{Panel regressions}

Dependent variable:

GROWTH = Annual rate of growth of per capita GNP. [Summers and Heston (1991)].

Explanatory Variables:

EDUC $=$ Percentage of school age population enrolled in primary school. [Source: The World Bank]. Missing years obtained by piecewise linear interpolations.

WGROWTH = Weighted average GDP per capita growth for the G-7 countries (U.S., Japan, Germany, France, U.K., Italy, and Canada). The weights are the share of the country GDP in the G-7 total GDP.

INDUST $=$ Dummy variable for industrial countries; takes the value of 1 for industrial countries, 0 otherwise.

Other variables defined above:

DEMOC, GROWTH(-1), GCHANGE(-1), LATIN, AFRICA. 
Table A.3

Probit Model of Government Change, 1960-82

(t-statistics in parentheses)

\begin{tabular}{lcc}
\hline Dependent Variable: & $\begin{array}{c}\text { Major } \\
\text { Government } \\
\text { Change } \\
\text { (GCHANGE) }\end{array}$ & $\begin{array}{c}\text { Government } \\
\text { Change } \\
\text { (MJCHANGE) }\end{array}$ \\
\hline CONSTANT & -0.663 & -1.437 \\
LATIN & $(-9.66)$ & $(-16.90)$ \\
& -0.120 & 0.284 \\
AFRICA & $(-1.77)$ & $(3.46)$ \\
& -0.356 & 0.070 \\
WGROWTH(-1) & $(-5.95)$ & $(0.95)$ \\
& 1.970 & -0.218 \\
GCHANGE(-1) & $(1.32)$ & $(-0.12)$ \\
& 0.326 & - \\
MJCHNGE(-1) & $(5.80)$ & 0.176 \\
& - & $(1.83)$ \\
EXADJ(-1) & & 0.224 \\
& 0.139 & $(3.45)$ \\
\hline \# of Observations & $(2.67)$ & 2733 \\
Log Likelihood & 2733 & -943.5 \\
\hline \hline
\end{tabular}

Note: The average estimated probabilities of a government change from these regressions are used in the cross-sectional regressions in Table 2. 